\title{
CATECHOLAMINE BINDING MACROMOLECULE IN SOLUBLE FRACTION OF RAT BRAIN*
}

\author{
Minoru INABA and Kunie KAMATA \\ Department of Pharmacology, Kyorin University School of Medicine, \\ Mitaka-shi, Tokyo 181, Japan \\ Accepted October 6, 1976
}

\begin{abstract}
A macromolecule having a high binding affinity to norepinephrine was isolated from the soluble fraction of rat brain, the partially purified macromolecule was prepared by extraction of the brain with isotonic sucrose containing $3.3 \mathrm{mM}$ $\mathrm{CaCl}_{2}$, ultracentrifugation, $35-50 \%$ ammonium sulfate precipitation and DEAEcellulose chromatography. DEAF-cellulose chromatography revealed that the macromolecule in the soluble fraction was separated in at least 4 fractions, 2 of which had both norepinephrine and cyclic AMP binding activity. A Scatchard plot indicated that a partially purified macromolecule showed 2 apparent binding affinity constants of $4.13 \times 10^{-7} \mathrm{M}$ and $3.70 \times 10^{-6} \mathrm{M}$ to norepinephrine. The effect of chemical or physical treatments on specific binding of the macromolecule to norepinephrine was studied in comparison with cyclic AMP binding to the macromoleculc. Trypsin treatment caused partial loss of norepinephrine binding activity, while cyclic AMP binding activity was completely losı. Heat treatment resulted in a complete disappearance of cyclic AMP binding activity, while norepinephrine binding activity was only slightly decreased. Dibenamine treatment caused a marked decrease both of norepinephrine binding activity and that of cyclic AMP. Dichloroisoproterenol had no effect on the binding activities. Cyclic AMP inhibited clearly norepinephrine binding to the macromolecule, while norepinephrine inhibited cyclic AMP binding only slightly. Norepinephrine binding to the macromolecule was essentially dependent on its catechol structure. The entity of the macromolecule is discussed on the basis of the findings.
\end{abstract}

Actions of catecholamines, as neurotransmitter or humoral hormone, are initiated by binding to a specific macromolecule in cell membrane of target tissue, thus leading to formation and accumulation of adenosine 3',5'-monophosphate (cyclic AMP) within the cell. Cell acceptors for catecholamines have been indirectly investigated by measuring the specific binding sites of these active agents in cell components such as plasma membrane. Several papers have recently described the isolation and identification of specific binding proteins to epinephrine or norepinephrine from plasma membrane, microsome or soluble fraction of some tissues (1-5), and evidence for $\beta$-adrenergic receptor nature of the binding proteins has been presented in some of these papers. However, $\beta$-adrenergic receptor nature of the protein of canine myocardial microsomes has come under question and catechol-0-methyltransferase, one of the catecholamine-metabolizing enzymes, has been postulated to be the entity of the norepinephrine binding protein (6).

We isolated the macromolecule capable of binding norepinephrine from a soluble

* This work was done in the Division of Bio-function Research, Bionedical Rescarch Laboratories, Jikei University School of Medicine, Minato-k t, lokyo 105, Japan. 
fraction of rat brain by DEAE-cellulose chromatography and the binding properties of the macromolecule were studied in comparison with cyclic AMP binding to the macromolecule.

\section{MATERIALS AND METHODS}

Dl-norepinephrine- $7{ }^{3} \mathrm{H}(10.8 \mathrm{Ci} / \mathrm{mmole})$ was obtained from New England Nuclear Corp. (Mass., U.S.A.) and adenosine-8- ${ }^{3} \mathrm{H}-3^{\prime}, 5^{\prime}$-monophosphate $(20.7 \mathrm{Ci} / \mathrm{mmole})$ from the Radiochemical Centre (Amersham, England). The following reagents were used : 1-norepinephrine (Sigma), dl-epinephrine (Sigma), dl-isoproterenol (Sigma), dopamine (TokyoKasei Chemicals, Japan), 1-dopa (Sigma), dl-metanephrine (Sigma), 1-phenylalanine (Nakarai Chemicals, Japan), dl-tyrosine (Nakarai Chemicals), dibenamine hydrochloride (Tokyo-Kasei Chem.), dichloroisoproterenol hydrochloride (Tokyo-Kasei Chem.), alumina (Woehlem), trypsin (Sigma), and DEAE-cellulose (Pharmacia).

Preparation for binding experiments: Male rats of Donryu strain weighing $200-300 \mathrm{~g}$ were sacrificed by instantaneous head amputation, immediately followed by removal of cerebra, which were cleaned by extirpation of small blood vessels and blood clots and washed with physiological saline. The tissue mass was weighed and homogenized in 10 volumes of $0.25 \mathrm{M}$ sucrose containing $3.3 \mathrm{mM} \mathrm{CaCl} \mathrm{m}_{2}$ with Potter-Elvehjem type of glass-teflon homogenizer at around $800 \mathrm{rpm}$ by $5 \mathrm{up}$ and down in ice-cold water. The homogenate was filtered through 2 sheets of gauze to remove the large tissue fragments, and centrifuged at $15,000 \times g$ for $20 \mathrm{~min}$ at $0^{\circ} \mathrm{C}$ in a Hitachi 65-P ultracentrifuge (Hitachi Co., Tokyo). The supernatant was further centrifuged at $100,000 \times g$ for $60 \mathrm{~min}$ at $0^{\circ} \mathrm{C}$ (RP-65 rotor) to separate the soluble fraction (cytosol fraction). Ammonium sulfate was dissolved at $35-50 \%$ concentration in the soluble fraction, and the precipitate was dissolved in $10 \mathrm{mM}$ Tris- $\mathrm{Cl}$ buffer (pH 7.4) containing $6 \mathrm{mM}$ mercaptoethanol and $10 \%$ glycerol (TMG buffer). This solution containing 3-5 $\mathrm{mg}$ protein per $\mathrm{ml}$ was dialyzed overnight against fresh TMG buffer at $3^{\circ} \mathrm{C}$. The dialyzate was used in some procedures of the norepinephrine and cyclic AMP binding experiments. For preparing the fractions of macromolecule of the soluble fraction, DEAEcellulose column chromatography was employed using the method of Kumon et al. (7) for separation of cyclic AMP binding protein. Before chromatography, TMG dialyzate was mixed with calcium phosphate, the macromolecule absorbed on calcium phosphate gel was eluted with potassium phosphate buffer ( $\mathrm{pH} 8$ ), and the eluate was again dialyzed against fresh TMG buffer overnight at $3^{\circ} \mathrm{C}$. The macromolecule in the dialyzate was separated by DEAEcellulose column chromatography. Following application of the macromolecule in the dialyzate on the top of DEAE-cellulose column (diameter, $10 \mathrm{~mm}$; length, $90 \mathrm{~mm}$ ) which was previously equilibrated with TMG buffer, elution was made with TMG buffer under the $\mathrm{NaCl}$ linear concentration gradient from 0.05 to $0.5 \mathrm{M}$ at $3^{\circ} \mathrm{C}$. Four $\mathrm{ml}$ fraction was successively collected, and protein concentration in the fraction was measured by the method of Lowry et al. (8). Aliquots of the fraction were used to measure the norepinephrine and cyclic AMP binding activitics.

Assay procedure for norepinephrine binding activity: Dl-norepinephrine- $7 .{ }^{3} \mathrm{H} \quad(10.8$ (i/nmole) was purified before use by atumina adsorption according to the method of Anton 
and Sayre (9). Purified ${ }^{3} \mathrm{H}$-norepinephrine in $0.1 \mathrm{~N}$ acetic acid was stored in a deep freezer $\left(-20^{\circ} \mathrm{C}\right)$ when it not in use. Immediately before use, 1 or $2, " 1$ of the stock solution of ${ }^{3} \mathrm{H}$-norepinephrine was diluted with 1 or $2 \mathrm{ml}$ of $0.1 \mathrm{M}$ sodium phosphate buffer $(\mathrm{pH} 7)$ or $10 \mathrm{mM}$ Tris- $\mathrm{Cl}$ buffer ( $\mathrm{pH} \mathrm{7)}$ containing $6 \mathrm{mM} \mathrm{MgCl}_{2}$ and sodium metabisulfite ( $2 \mathrm{mg} \%$ ). Incubation was carried out usually in 0.5 or $1.0 \mathrm{ml}$ of the same buffer as above at $3^{\circ} \mathrm{C}$ for $3 \mathrm{hr}$ in the ratio of approx. 33 pmoles of ${ }^{\mathrm{H}} \mathrm{H}$-norepinephrine to $\mathrm{mg}$ of the macromolecule. In a blank incubation run simultaneously, $50 \mu \mathrm{g}$ of unlabeled 1-norepinephrine was added to the incubation mixture containing brain macromolecule and ${ }^{3} \mathrm{H}$-norepinephrine. $\mathbf{~} \mathrm{m}$ mediately after incubation, $5 \mathrm{ml}$ of fresh and cold buffer was added to the incubation mixture, which was then passed through a Millipore disk filter (pore size, $0.45, \mu \mathrm{m}$; diameter $25 \mathrm{~mm}$, HAWP 0250, Millipore Corp., U.S.A.) under vacuum in a cold room $\left(3^{\circ} \mathrm{C}\right)$. After 4 successive washes of the disk filter with $5 \mathrm{ml}$ of the same fresh buffer at each time, bound ${ }^{3} \mathrm{H}$ norepinephrine to macromolecule on the filter was measured in a liquid scintillation spectrometer. The Millipore filter was transferred into a vial and dissolved with $1 \mathrm{ml}$ of methylcellulosolve. Using $10 \mathrm{ml}$ of Bray's solution (10) as a scintillation liquid, the radioactivity of ${ }^{3} \mathrm{H}$-norepinephrine bound was measured at least on 2 different occasions for a sample for $10 \mathrm{~min}$ in Tri-Carb liquid scintillation spectrometer (Model 3224, Packard Instrument Co., U.S.A.). Counting efficiency for ${ }^{8} \mathrm{H}$ was $19.4 \%$ in Bray solution alone and $15.8 \%$ in Bray solution and methylcellulosolve mixture. Counting error was within $-5 \%$ and the counting values exceeding this range of error were discarded. The radioactivity of bound ${ }^{3} \mathrm{H}$-norepinephrine was obtained by subtracting $\mathrm{cpm}$ of the blank incubation from $\mathrm{cpm}$ of the sample incubation. Triple determinations for a sample were carried out simultaneously.

Assay procedure for cyclic AMP binding activity: Adenosine-8- ${ }^{3} \mathrm{H}-3^{\prime}, 5^{\prime}$-monophosphate $(20.7 \mathrm{Ci} / \mathrm{mmole})$ was used as a ligand for binding to the macromolecule of rat brain, and the R-protein assay of Kumon et al. (7) was followed to measure the cyclic AMP binding activity of the brain macromolecule.

Minor modifications in the measurement of norepinephrine as well as cyclic AMP binding activity were sometimes made and such are described under Results. A Scatchard plot (11) was employed for the analysis of norepinephrine binding kinetics. Protein concentration was measured by the method of Lowry et al. (8).

\section{RESULTS}

A soluble fraction of rat brain was found to contain a macromolecule with binding activity to norepinephrine. Aliquots of the macromolecule containing various concentrations of protein (0.02-1.32 mg/incubation mixture) were incubated with 6 pmoles of ${ }^{3} \mathrm{H}$-norepinephrine, and the bound ${ }^{\mathrm{s}} \mathrm{H}$-norepinephrine $(b)$ measured by the method described under Methods. As seen in Fig. 1, $b$ increased almost rectilineally at protein concentrations from 0.02 to $0.2 \mathrm{mg} / \mathrm{ml}$, reached the maximum at about $0.5 \mathrm{mg} / \mathrm{ml}$, and decreased at the concentrations above $0.5 \mathrm{mg} / \mathrm{ml}$. Non-specific binding of ${ }^{3} \mathrm{H}$-norepinephrine measured by the incubations in the presence of an excess amount of unlabeled norepinephrine was so low that it was disregarded. The fall of $b$ upon increasing protein con- 


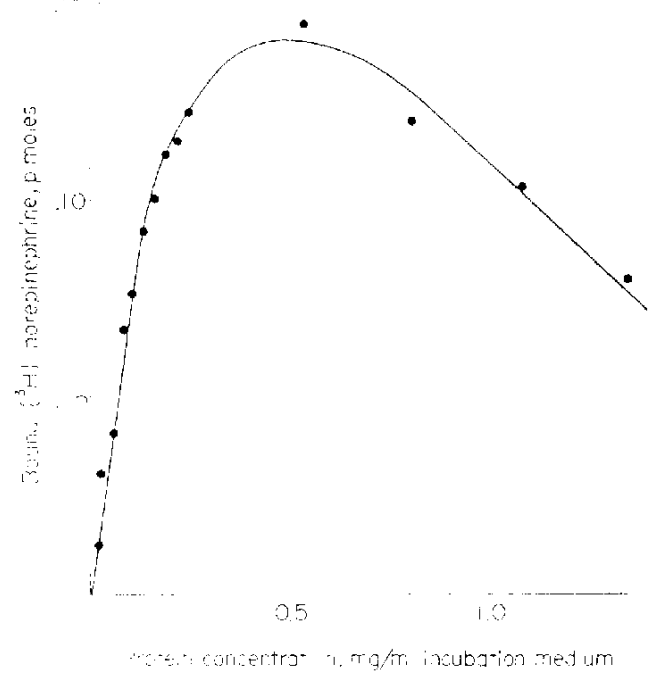

FIG. 1. Norepinephrine binding to the macromolecule in soluble fraction of rat brain at various concentrations of protein. $0.1 \mathrm{ml}$ aliquots of the rat brain macromolecule (35-50\% ammonium sulfate fraction in 100,000 $\times g$ cytosol of $0.25 \mathrm{M}$ sucrose homogenate of 5 cerebra) having $0.02-1.2 \mathrm{mg}$ protein were incubated with a fixed concentration of $\left[{ }^{3} \mathrm{H}\right]$ norepinephrine $(6 \mathrm{nM})$ in $1.0 \mathrm{ml}$ of $0.1 \mathrm{M}$ sodium phosphate buffer, $\mathrm{pH} 7$, containing $6 \mathrm{mM} \mathrm{MgCl}$ and sodium metabisulfite $(20 / \mathrm{g} / \mathrm{ml})$ at $3^{\circ} \mathrm{C}$ for $3 \mathrm{hr}$. Bound $\left.{ }^{3} \mathrm{H}\right]$ norepinephrine was separated by Millipore fill ration and measured by the method described under Methods.

centration over $0.5 \mathrm{mg} / \mathrm{ml}$ would be attributed to factors other than the quenching effect of unknown substances in the soluble fraction. Thus, almost constant radioactivities were obtained when a fixed amount of ${ }^{3} \mathrm{H}$-norepinephrine in various concentrations of protein over $0.5 \mathrm{mg} / \mathrm{ml}$ was filtered through a Millipore disk filter.

Two fractions of the macromolecule having both norepinephrine and cyclic AMP binding activity were isolated from a soluble fraction by DEAE-cellulose column chromatography. Before chromatography, the soluble fraction of 5 cerebra containing $37.6 \mathrm{mg}$ protein in $22 \mathrm{ml}$ of TMG buffer was treated with calcium phosphate and the macromolecule adsorbed to calcium phosphate gel was eluted in potassium phosphate buffer $(\mathrm{pH} 8)$. After dialyzing the eluate against TMG buffer at $3^{\circ} \mathrm{C}$ overnight, the macromolecule in the eluate was chromatographed on DEAE-cellulose column (diameter, $10 \mathrm{~mm}$; length, $90 \mathrm{~mm}$ ) in a cold room $\left(3^{\circ} \mathrm{C}\right)$. Elution was made with $20 \mathrm{ml}$ of TMG buffer, and successively with 140 $\mathrm{ml}$ of TMG buffer under linear concentration gradient of $\mathrm{NaCl}$ from 0.05 to $0.5 \mathrm{M}$. The flow speed was approx. $4 \mathrm{ml} / \mathrm{hr}$, and the $4 \mathrm{ml}$ fractions were continuously collected. After measurement of optical density at $280 \mathrm{~nm}, 0.1$ or $0.2 \mathrm{ml}$ aliquots of each fraction were subjected to norepinephrine and cyclic AMP binding assay, in which 6 pmoles of ${ }^{9} \mathrm{H}$-norepinephrine or 10 pmoles of ${ }^{3} \mathrm{H}$-cyclic AMP were used as the ligand. As seen in Fig. 2, 2 macromolecule fractions were separated, and the elution pattern of norepinephrine binding macromolecule coincided well with that of cyclic AMP binding protein. Fraction A with a peak at fraction number 21 was further used for the kinetics of norepinephrine binding. 


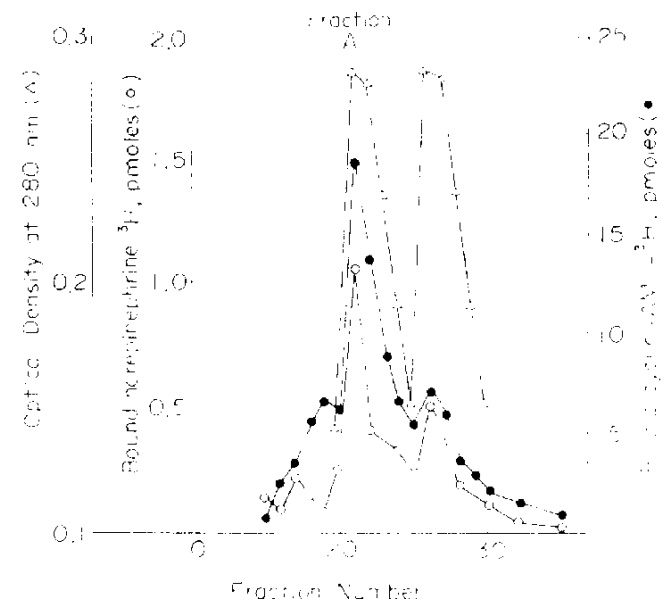

Fic. 2. DE AE-cellulose chromatography of the rat brain cytosol. $3550 \%$ ammonium sulfate fraction in $100,000 \mathrm{~g}$ supernatant of $0.25 \mathrm{M}$ sucrose homogenate of 5 cerebra was dialyzed against TMG buffer and the dialyzate $(22 \mathrm{ml}$ containing $37.6 \mathrm{mg}$ protein) was treated with calcium phosphate. The macromoleculc absorbed to calcium phosphate gel was eluted with potassium phosphate buffer, pH 8 and the cluate was dialyzed against TMG buffer. The second dialyzate was chromatographed on DEAF-cellulose column (diameter, $10 \mathrm{~mm}$ : length, $90 \mathrm{~mm}$ ) in a cold room (3 C), firstly by elution with $20 \mathrm{~m} /$ of TMG buffer and then successively with $140 \mathrm{ml}$ of TMG buffer containing $0.05-0.5 \mathrm{M} \mathrm{NaCl}$ in the linear concentration gradient. Flow speed was approx. $4 \mathrm{ml} / \mathrm{hr}$, and $4 \mathrm{ml}$ fractions were successively collected. After measurement of optical density at $280 \mathrm{~nm}$, the aliquots of each fraction were subjected to the measurements of $\left[{ }^{3} \mathrm{H}\right]$ norepinephrine and $\left[{ }^{3} \mathrm{H}\right]$-cyclic AMP binding activities by the method described under Methods. $\triangle$ : optical density at $280 \mathrm{~mm}, \mathrm{O}$ : bound $\left[{ }^{3} \mathrm{H}\right]$-cyclic $\triangle \mathrm{MP}, \quad$ : bound $\left[{ }^{3} \mathrm{H}\right]$ norepinephrine.

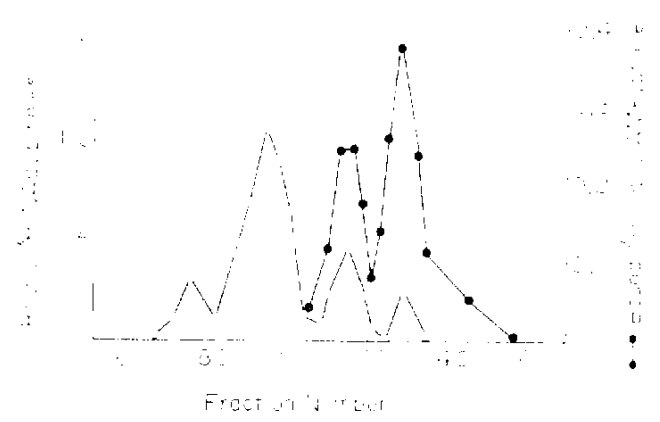

Fici. 3. DEAE-cellulose chromatography of the rat brain cytosol. 35-50\% ammonium sulfate fraction in $100,000: g$ supernatant fraction of 5 rat cerebra- $0.25 \mathrm{M}$ sucrose homogenate was dialyzed against TMG buffer and the dialyzate $(38.5 \mathrm{~m}$ ) TMG buffer containing $22.76 \mathrm{mg}$ protein) was treated with calcium phosphate. The macromolecule absorbed to calcium phosphate gel was cluted with $0.2 \mathrm{M}$ potassium phosphate buffer $(\mathrm{pH} 8.1)$, and the eluate was again dialyzed against TMG buffer. The second dialyzate was chromatographed on DEAE-cellulose column (diameter, $20 \mathrm{~mm}$; length, $175 \mathrm{~mm}$ ) in a cold room $(3 \mathrm{C}$ ). Elution was carried out with $100 \mathrm{ml}$ of TMG buffer containing $0.05 \mathrm{M} \mathrm{NaCl}$, and then successively with $300 \mathrm{ml}$ of TMG buffer under $\mathrm{NaCl}$ concentration gradient from 0.05 $0.5 \mathrm{M}$. Flow speed was approx. $18 \mathrm{ml} / \mathrm{hr}$, and $2.5 \mathrm{ml}$ fractions were successively collected. The aliquots of each fraction were subjected to the measurements of $\left[{ }^{3} \mathrm{H}\right]$ norepinephrine and $\left[{ }^{3} \mathrm{H}\right]$-cyclic AMP binding activities by the method described under Methods. : bound $\left[{ }^{3} \mathrm{H}\right]$-cyclic AMP. : bound $\left[{ }^{3} \mathrm{H}\right]$ norepinephrine. 
Other DEAE-cellulose chromatography in almost the same conditions as described above, except that $2.5 \mathrm{ml}$ fractions were continuously collected, revealed that more than 2 fractions (4 fractions) of the macromolecule were involved in the soluble fraction of rat brain (Fig. 3). Two of these possessed the binding activities to both norepinephrine and cyclic AMP.

Different concentrations of ${ }^{3} \mathrm{H}$-norepinephrine $\left(10^{-5}-10^{-9} \mathrm{M}\right)$ were incubated with a fixed amount of the macromolecule in Fraction $\mathrm{A}(54 \mu \mathrm{g}$ protein $/ 0.2 \mathrm{ml})$ in $0.5 \mathrm{ml}$ of $0.06 \mathrm{M}$ sodium phosphate buffer ( $\mathrm{pH} 7-7.4$ ) containing $4 \mathrm{mM}$ Tris, $4 \%$ glycerol and $3.6 \mathrm{mM} \mathrm{MgCl}$ at $3^{\circ} \mathrm{C}$ for $3 \mathrm{hr}$, and the $b$ was measured by the Millipore filtration method. As shown in Fig. 4 , the increase of $b$ upon increasing ${ }^{3} \mathrm{H}$-norepinephrine added showed a sigmoid curve with the saturated level (maximum $b$ level) at around $30 \mathrm{nM}$ for the concentration of ${ }^{3} \mathrm{H}$ norepinephrine over $10^{-5} \mathrm{M}$. When $1 \times 10^{-5} \mathrm{M}{ }^{3} \mathrm{H}$-norepinephrine was incubated with 54 $\mu \mathrm{g}$ protein of the macromolecule, the formed bound ${ }^{3} \mathrm{H}$-norepinephrine was calculated to be $55.6 \times 10^{-5}$ moles/g protein, assuming that the norepinephrine incubated was about 55 -fold concentrated in the macromolecule. Non-specific binding of ${ }^{3} \mathrm{H}$-norepinephrine was so low that it could be disregarded. Table I summarizes the amounts bound at various concentrations of ${ }^{3} \mathrm{H}$-norepinephrine added (Table 1). Fig. 5 shows the curve obtained by a Scatchard plot (11) for norepinephrine binding to the macromolecule in Fraction $\mathrm{A}$.

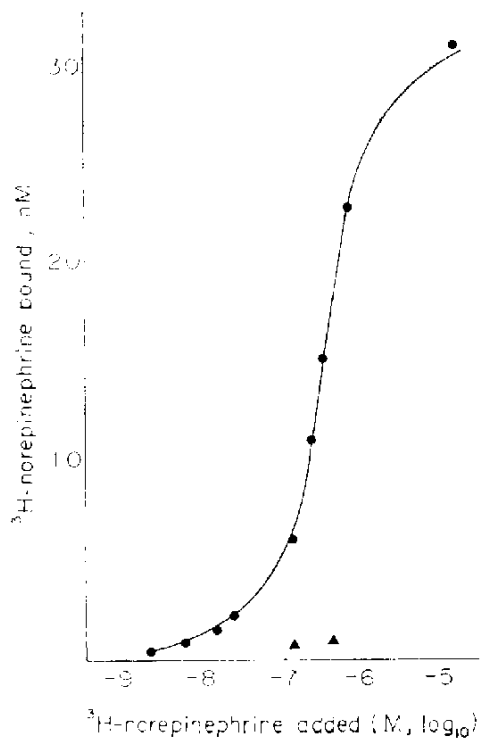

Fig. 4. Norepinephrine binding to the rat brain macromolecule at different concentrations of added $\left[{ }^{8} \mathrm{H}\right]$ norepinephrine. The aliquots of the macromolecule in Fraction A $(0.2 \mathrm{ml}$ containing $54 \mu \mathrm{g}$ protein) separated by DEAE-cellulose chromatography from the rat brain cytosol were incubated with the different concentrations $\left(3 \times 10^{-8}-10^{-5} \mathrm{M}\right)$ of $\left[{ }^{8} \mathrm{H}\right]$ norepinephrine in $0.5 \mathrm{ml}$ of $0.06 \mathrm{M}$ sodium phosphate buffer ( $\mathrm{pH} 7-7.4)$ containing $4 \mathrm{mM}$ Tris- $\mathrm{HCl}, 2.4 \mathrm{mM}$ mercaptoethanol, $4 \%$ glycerol, $3.6 \mathrm{mM} \mathrm{MgCl}$, and sodium metabisulfite $(20 \mu \mathrm{g} / \mathrm{ml})$ at $3{ }^{\circ} \mathrm{C}$ for $3 \mathrm{hr}$. Bound $\left[{ }^{\mathrm{a}} \mathrm{H}\right.$ ]norepinephrine was separated from the incubation mixture by the Millipore filtration method and measured as described under Methods. $\mathbf{A}$ : bound $\left[{ }^{3} \mathrm{H}\right]-$ norepinephrine of blank incubations with $50 / 4 \mathrm{~g}$ of unlabelled norepinephrine, - bound $\left[{ }^{3} \mathrm{H}\right]$ norepinephrine of the incubations without unlabeled norepinephrinc. 
TABLE 1. Binding activities of norepinephrine at various concentrations to the macromolecule in a cytosol fraction of rat brain

\begin{tabular}{cccccc}
\hline (NE) total & (NE) bound & \multicolumn{2}{c}{ (NE) bound } & (NE) unbound & (NE) bound \\
M. & M. & $\%$ & $\begin{array}{c}\text { pmoles } / \mathrm{mg} \\
\text { protein }\end{array}$ & M. & (NE) unbound \\
$3.0 \times 10^{-9}$ & $4.0 \times 10^{-10}$ & 13.3 & 7.4 & $2.60 \times 10^{-9}$ & 0.154 \\
$7.5 \times 10^{-9}$ & $8.0 \times 10^{-10}$ & 10.7 & 14.8 & $6.70 \times 10^{-4}$ & 0.119 \\
$1.5 \times 10^{-8}$ & $1.4 \times 10^{-9}$ & 9.3 & 25.9 & $1.36 \times 10^{-8}$ & 0.103 \\
$3.0 \times 10^{-8}$ & $2.4 \times 10^{-9}$ & 8.0 & 44.4 & $2.76 \times 10^{-8}$ & 0.087 \\
$1.05 \times 10^{-7}$ & $6.1 \times 10^{-8}$ & 5.8 & 138.9 & $9.89 \times 10^{-8}$ & 0.061 \\
$3.0 \times 10^{-8}$ & $1.2 \times 10^{-8}$ & 4.0 & 222.2 & $2.88 \times 10^{-\gamma}$ & 0.041 \\
$5.0 \times 10^{-7}$ & $1.5 \times 10^{-8}$ & 3.0 & 277.8 & $4.85 \times 10^{-7}$ & 0.031 \\
\hline
\end{tabular}

Binding activities of norepinephrine at various concentrations $\left(3 \times 10^{-9}-5 \times 10^{-7} \mathrm{M}\right)$ to the macromolecule in Fraction A separated from a soluble fraction of rat brain by DEAE-cellulose chromatography were determined by the procedure described under Methods and Results. (NE)total: the total concentration of norepinephrine incubated, (NE)bound: the concentration of norepinephrine bound, M, and (NE)unbound: the concentration of unbound norepinephrine. $M$.

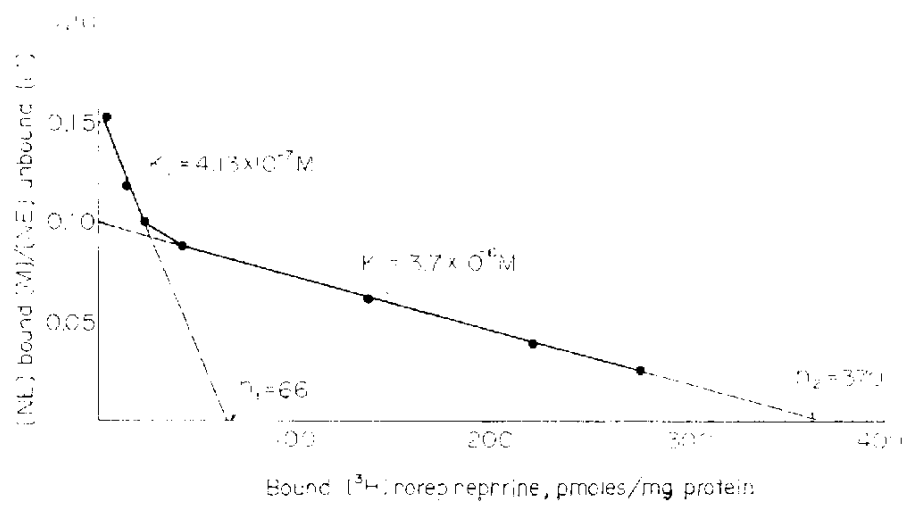

Fig, 5. Scatchard plot for norepinephrine binding to the macromolecule in Fraction A separated from a cytosol of rat brain by DEAE-cellulose chromatography. Ratio of bound $\left[{ }^{3} \mathrm{H}\right]$ norepinephrine $\left[(\mathrm{NE})_{\text {bound }}, \mathrm{M}\right]$ to unbound $\left[{ }^{3} \mathrm{H}\right]$ norepinephrine $\left[(\mathrm{NE})_{\text {unbound, }} \mathrm{M}\right]$ was plotted against bound $\left[{ }^{3} \mathrm{H}\right]$ norepinephrine (pmoles $/ \mathrm{mg}$ protein) obtained by the incubation of macromolecule in Fraction A with $10^{-9}-10^{-}$: $\mathrm{M}$ of $\left[{ }^{8} \mathrm{H}\right]$ norepinephrine added.

Ratios of bound norepinephrine $(M)$ to unbound norepinephrine $(M)$ were plotted against bound norepinephrine (pmoles/mg protein). It gives a straight line when only one binding site is present, but from the shape of the curve actually obtained, it appeared that there was more than one binding site in the macromolecule of Fraction A. An approximate determination of the number of binding sites ( $n$ ) and the apparent dissociation constant for the binding can be made by extrapolation of the curve to both ordinate and abscissa intercepts. There was a binding site with higher affinity $\left(n_{1}=66\right.$ pmoles $/ \mathrm{mg}$ protein) with an apparent dissociation constant of $4.13 \times 10^{-7} \mathrm{M}$ and an another binding site with less affinity $\left(\mathrm{n}_{2}=370\right.$ 
pmoles/mg protein) having an apparent dissociation constant of $3.70 \times 10^{-6} \mathrm{M}$.

Chemical and physical treatments of the macromolecule in Fraction A resulted in changes in the norepinephrine and cyclic AMP binding activities. Fraction A was treated by incubation with $0.05 \%$ trypsin in TMG buffer $\left(\mathrm{pH} \mathrm{7.4)}\right.$ at $37^{\circ} \mathrm{C}$ for $30 \mathrm{~min}$. The aliquots were then incubated with ${ }^{3} \mathrm{H}$-norepinephrine or ${ }^{3} \mathrm{H}$-cyclic AMP, and the $b$ was measured. The control incubation was carried out without trypsin or with trypsin that was preheated at $100^{\circ} \mathrm{C}$ for 5 min. As seen in Fig. 6, Fraction A lost its binding activity to norepinephrine to about $20 \%$ of the control level, while cyclic AMP binding activity was completely lost. A marked difference of changes in the norepinephrine and cyclic AMP binding activities was found when the macromolecule of Fraction A was heat-treated. As seen in Fig. 6, the heat treatment of Fraction $\mathrm{A}$ at $80^{\circ} \mathrm{C}$ for $10 \mathrm{~min}$ resulted in a complete loss of cyclic AMP binding activity in contrast to only $20 \%$ reduction in the norepinephrine binding activity. By heat treatment at $100^{\circ} \mathrm{C}$ for $10 \mathrm{~min}$ of the fraction, norepinephrine binding activity was

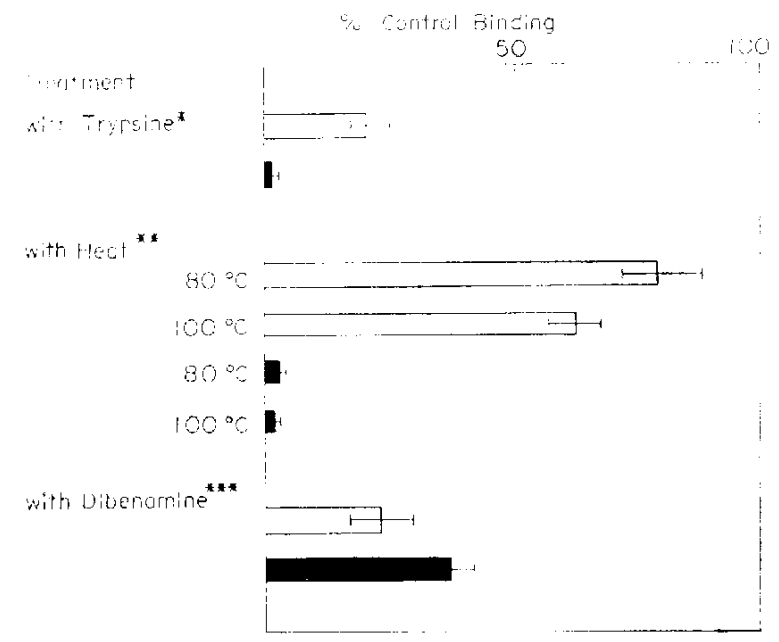

Fig. 6. Elfect of some physical or chemical treatments of rat brain macromolecule on its binding activity to norepinephrine as well as cyclic AMP. Fraction A containing the macromolecule ( $0.27 \mathrm{mg}$ protein/ml TMG buffer) separated from a cytosol fraction of rat brain by DEAE-cellulose chromatography (Fig. 2) was treated with a physical or chemical procedure and the changes in its binding activity to norepinephrine and cyclic AMP were studied as described under Methods. *The aliquot of Fraction A was incubated with trypsin $(0.05 \%)$ at $37^{\circ} \mathrm{C}$ for $30 \mathrm{~min}$ or with the samc concentration of trypsin preheated at $100^{\circ} \mathrm{C}$ for $5 \mathrm{~min}$ (control). **The aliquol of Fraction $\mathrm{A}$ was heated at $80^{\circ} \mathrm{C}$ or $100^{\circ} \mathrm{C}$ for 10 min before incubation with $\left[{ }^{3} \mathrm{H}\right]$ norepinephrine or $\left[{ }^{3} \mathrm{H}\right]$ cyclic AMP. ${ }^{* * *}$ The aliquot of Fraction $\mathrm{A}$ was dialyzed against TMG buffer containing $0.5 \mathrm{mM}$ dibenamine hydrochloride at $3^{\circ} \mathrm{C}$ overnight or dialyzed in the same way against TMG buffer containing the velicle alone (control). The $0.1 \mathrm{ml}$ aliquots of the control and the treated samples were incubated with 6 pmoles of $\left[{ }^{3} \mathrm{H}\right]$ norepinephrine in $1.0 \mathrm{ml}$ of $0.1 \mathrm{M}$ sodium phosphate buffer $\left(\mathrm{pH}\right.$ 7) containing $\mathrm{MgCl}_{2}(6 \mathrm{mM})$ at $3{ }^{\circ} \mathrm{C}$ for $3 \mathrm{hr}$. [3 H]cyclic AMP binding activity to the macromolecule treated was assayed by the method of Kumon et al. (7) as described under Methods. The \% control binding was shown in the this figure, $\square:\left[{ }^{3} \mathrm{H}\right]$ norepinephrine binding,

$\left.{ }^{3} \mathrm{H}\right\rceil$ cyclic AMP binding, $\mid-[$ : S.D. 
found intact at the level of about $60 \%$ of the control (Fig. 6). Direct influence of $a$ - and i3-adrenergic blocking agents to norepinephrine and cyclic AMP binding activities of the macromolecule in Fraction $A$ was studied, and the result is shown in Fig. 6. After dialysis of Fraction $A$ against TMG buffer containing $0.5 \mathrm{mM}$ dibenamine hydrochloride or TMG alone at $3^{\circ} \mathrm{C}$ for $24 \mathrm{hr}$, the aliquots of the treated samples were assayed for their binding activities to norepinephrine and cyclic AMP. As shown in Fig. 6, norepinephrine binding activity of the macromolecule was found to decrease with dibenamine treatment to $23 \%$ that of the control, and cyclic AMP binding activity was also decreased to $37 \%$ of the control.

raBLF 2. Eflect of eyclic AMP on norepinephrine hinding to the macromolecule in rat brain cylosol

\begin{tabular}{|c|c|c|c|}
\hline $\begin{array}{l}\text { Cyclic AMP added } \\
\text { (nmoles) }\end{array}$ & $\begin{array}{c}\text { [3H Horepinephrine bound } \\
\text { (pmoles mg proien! }\end{array}$ & $\begin{array}{l}\text { Control } \\
\text { linding }\end{array}$ & $\begin{array}{l}\text { Inhibirion } \\
\text { rate }(\%)\end{array}$ \\
\hline 0 & $0.29 \quad 0.06^{*}$ & 100.0 & $\cdots-$ \\
\hline 0.6 & $0.15 \quad 0.02$ & 51.7 & 48.3 \\
\hline 2.4 & $0.04: 0.04$ & 13.8 & 86.2 \\
\hline
\end{tabular}

The aliquots of fraction A containing $27 / 2$ protein in $0.1 \mathrm{ml}$ separated from a soluble fraction of rat brain by DEAF-callulose chromatography were incubated with 3.1 pmoles of $\left.{ }^{3} \mathrm{H}\right]$ norepinephrine in $1.0 \mathrm{~m}$ of $0.01 \mathrm{M}$ Tris- $\mathrm{HCl}$ bufler, pH 7 , containing $25 \mathrm{mM}$ $\mathrm{MgCl}_{2}$ and theophylline $(7.5 \mathrm{mMl}$ ) a 3 C for $3 \mathrm{hr}$ with or without unlabeled cyclic AMP in the amounts indicated in the table. The amount of bolind $\left[{ }^{3} \mathrm{H}\right.$ ]norepinephrine (pmoles/mg protein), \% control birding and inhibition rate arc shown *Mean $\therefore$ S.D. $(\mathrm{N}-: 4)$

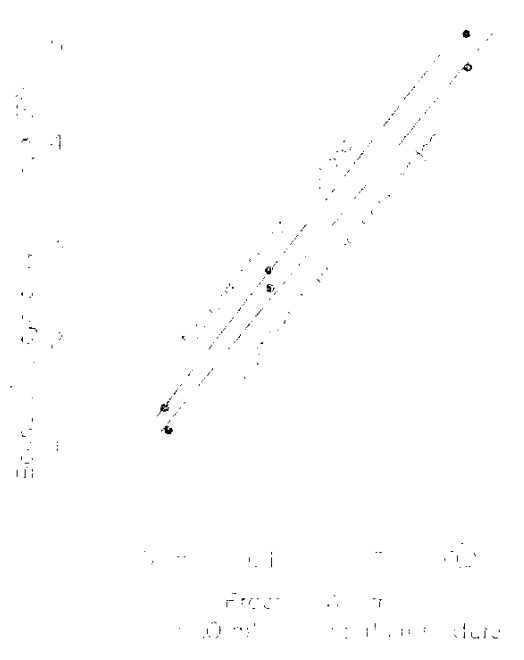

Fur. 7. Effect of norepinephrine on cyclic AMP binding to the macromolecule in Fraction $A$ separated froti i Giosol fraction of rat brain by DEAE-celluloso chromatography. The it diferiit volumes of Fracion A $(0.27 \mathrm{mg}$ protein/ml 1MG buffer solution) was separately incubated with 10 pmoles of [3Heyclic AMP with or without 10 pmoles of mnabeles l-norepinephrine as described under Methods. The assay procedure of $\left[{ }^{3} \mathrm{H}\right]$ cyclic AMP bound to the macromolecule was based on the assay procedure of R-protein by Kumon ot al. (7). 
A reduction in norepinephrine binding activity was greater than that of cyclic AMP binding activity with dibenamine treatment. Treatment of the macromolecule in Fraction A with $0.5 \mathrm{mM}$ dichloroisoproterenol in the same manner produced no change in the norepinephrine and cyclic AMP binding activities.

Norepinephrine binding activity of the macromolecule in Fraction A was clearly suppressed by cyclic AMP. As shown in Table 2, the cyclic nucleotide in such low concentrations as $0.6 \times 10^{-6}$ and $2.4 \times 10^{-6} \mathrm{M}$ inhibited the norepinephrine binding by $48 \%$ and $86 \%$, respectively. On the other hand, cyclic AMP binding activity to the macromolecule was suppressed only slightly by addition of norepinephrine in the incubation mixture, as shown in Fig. 7. Adenosine triphosphate at such a high concentration as $2.4 \times 10^{-3} \mathrm{M}$ inhibited the norepinephrine binding activity of the macromolecule to $63 \%$ of the control in the presence of $17.5 \mathrm{mM} \mathrm{MgCl}$.

Specificity of norepinephrine binding to the macromolecule of rat brain soluble fraction was studied on the basis of displacement effect of various catecholamines and the related compounds on ${ }^{8} \mathrm{H}$-norepinephrine binding. The aliquots of the fraction $(0.38 \mathrm{mg}$ protein/ $0.1 \mathrm{ml}$ of $0.1 \mathrm{M}$ phosphate buffer, $\mathrm{pH}$ 7) were incubated with $12-13$ pmoles of ${ }^{8} \mathrm{H}$-norepine-

TABLE 3. Structure and displacement effect of catecholamines and structurally related compounds on norepinephrine binding to the macromolecule in the soluble fraction of rat brain

Displacement
effect

* At a fixed concentration of unlabeled compounds added to incubation mixture of the macromolecule in rat brain cytosol and $\left[{ }^{3} \mathrm{H}\right]$ norepinephrine under the same conditions, the inhibition rates of $\left[{ }^{3} \mathrm{H}\right]$ norepinephrine binding to the macromolecule were measured by the method described under Methods, and expressed as displacement effects when the inhibition rate due to unlabeled 1-norepinephrine was standardized to be 1.00 . 
phrine in $1.0 \mathrm{ml}$ of $0.1 \mathrm{M}$ sodium phosphate buffer, $\mathrm{pH} 7$, containing $6 \mathrm{mM} \mathrm{MgCl}_{2}$ in the presence of 3-6 $\times 10^{-6} \mathrm{M}$ of unlabelled 1-norepinephrine at $3^{\circ} \mathrm{C}$ for $22 \mathrm{hr}$. Inhibition rates of ${ }^{3} \mathrm{H}$-norepinephrine binding ranged between 60 and $67 \%$ against the controls that did not contain unlabeled 1-norepinephrine in the incubation mixture. These values of inhibition rate were standardized as 1.00 and the inhibition rates of the other catecholamines and related compounds examined simultaneously were expressed as relative numbers to 1.00 and termed the displacement effect. The chemical structures of the tested compounds and their displacement effects are summarized in Table 3. dl-Epinephrine, dopamine and 1-dopa exhibited almost the same displacement effect as that of 1-norepinephrine. d-Isomer of norepinephrine also showed the same degree of displacement effect as 1-isomer. dl-Isoproterenol gave the value of 0.82 of displacement effect, and $\mathrm{dl}$-metanephrine 0.43 that was almost half of that of di-epinephrine. Inhibition rates due to 1-phenylalanine and $\mathrm{dl}$ tyrosine were only $1 / 10-3 / 10$ that of norepinephrine. Thus, the binding specificity of the macromolecule was entirely dependent on the catechol structure of catecholamines and related compounds.

\section{DISCUSSION}

Our experiments indicate the following: a macromolecule capable of binding norepinephrine with a relatively high binding affinity is involved in a soluble fraction of rat brain, the macromolecule is separated into at least 4 fractions by DEAE-cellulose chromatography, 2 of these fractions possess both norepinephrine and cyclic AMP binding activities, the macromolecule is relatively stable to heat-treatment in norepinephrine binding, while it is not stable in cyclic AMP binding, the small amount of cyclic AMP clearly inhibits norepinephrine binding to the macromolecule, while norepinephrine inhibits only slightly cyclic AMP binding to the macromolecule, and the catechol structure is essentially responsible for norepinephrine binding to the macromolecule.

Isolation and identification of proteins with high binding affinity to catecholamines have been described recently in tissues such as liver, heart, fat cell, spleen capsule, erythrocyte, and brain $(1-6,12-15,18,19)$. To elucidate the molecular basis of actions of catecholamines, specific acceptors for these bioactive agents have been researched with membraneous components of the target tissue cell, and epinephrine or norepinephrine binding proteins with $10^{-7}-10^{-8} \mathrm{M}$ order of binding affinity constants have been isolated and identified from plasma membranes and microsomal fractions. Almost all of these proteins have been considered to be $\beta$-adrenergic receptor on the basis of parallelism of the binding activity and adenylate cyclase activity. However, in a recent dispute between 2 groups of investigators, the question concerning the real entity of catecholamine-binding proteins being $\beta$-adrenergic receptor has been raised. One group of investigators has postulated that catechol-0-methyltransferase, one of the catecholamine-metabolizing enzymes, should be a candidate for the catecholamine-binding proteins. This postulation was made on the facts that a) d-norepinephrine, an inert catecholamine, inhibited norepinephrine binding to canine myocardial microsomes to the same extent as did 1-norepinephrine, b) the binding 
was not specific to each of isoproterenol, epinephrine and norepinephrine, but was specific for their catechol group, resembling COMT, c) soterenol, a potent $\beta$-adrenergic agent, inhibited only slightly norepinephrine binding to the microsomes, and d) as with COMT, norepinephrine binding was inhibited by p-chloromercuribenzoate, EDTA and COMT inhibitors such as tropolone (6). This postulation was opposed by another groups of investigators $(14,16)$. Norepinephrine binding protein has recently been isolated from a soluble fraction of mouse brain (15). Such a finding indicated that catecholamine-binding proteins were involved not only in the particulate components but in the cytosol fraction of the tissue cell.

In intact tissue, a receptor can be defined as an entity with which the active binding ligand interacts to cause a change in ionic permeability or other physiological responses such as activation of adenylate cyclase; such criterion cannot be applied once the receptor has been removed from the cellular component. In in titro experiments, the receptor criterion is mainly based on saturability of the binding, reversibility of the binding reaction, high affinity constant comparable to the concentration which produces the physiological actions, specificity of the binding, and inhibitory effect of $\alpha$ - or $\beta$-adrenergic blocking agents on the binding. The macromolecule isolated from a soluble fraction of rat brain was saturable with norepinephrine in the binding (Fig. 4). By treatment of "H-norepinephrine-macromolecule complexes with $1 \mathrm{NHCl}$, free ${ }^{3} \mathrm{H}$-norepinephrine was liberated, indicating a possible reversibility of the binding. Binding site of the macromolecule showed 2 apparent dissociation constants, $4.13 \times 10^{--}$and $3.76: 10^{-6} \mathrm{M}$ (Fig. 5). These values seem much higher than the concentrations of norepinephrine or epinephrine for producing physiological responses such as contraction of blood vessels. The dissociation constants obtained, hosever, were almost in the same range as $1.04 \% 10^{-i}$ and $1.33 \cdot 10^{-6}, \mathrm{~W}$ in norepinephrine binding to canine myocardial microsomes (17) and $2.34 \times 10^{-8}$ and $4.73 \times 10^{-7} \mathrm{M}$ in norepinephrinc binding to protein of a soluble fraction of mouse brain (15). Almost all macromolecules isolated from a variety of tissue cells have shown $10^{-3} \cdot 10^{-3} \mathrm{M}$ order of dissociation constants in catecholamine binding in vitro. Specificity of norepinephrine binding to rat brain macromolecule, similar to other norepinephrine binding proteins reported previously, was completely dependent on its catechol structure (Table 3 ). Catechol itself produced the same degree of displacement effect on norepinephrine binding as 1-norepinephrine, and metanephrine showed about 1/2 displacement effect of epinephrine. Thus, the brain macromolecule does not have particular ability to distinguish norepinephrine from other catecholatmines as a binder. The relatively high displacement effect of serotonin (0.8) cannot be explained at present. The brain macromolecule might have high binding affinity not only 10 cattcholamines but to indolamine. Although the binding activity of the macromolecule of rat brain was inhibited clearly by dibenamine and not at all by dichloroisoproterenol, the macromolecule cannot be concluded to have an $\alpha$-adrenergic receptor nature because dibenamine is known to be a non-specific alkylating agent. A marked inhibition of cyclic $A M P$ binding to the macromolecule by dibenamine might be caused by the non-specific alkylating action of the reagent. However, the macromolecule obtained by sonication of 
a crude synaptosome fraction of rat brain lost its binding activity to norepinephrine or dopamine remarkably by treatment with phenoxybenzamine and phentolanine (20).

Isolated macromolecule fraction from rat brain cytosol consists of at least 4 different macromolecule fractions capable of binding norepinephrine (Fig. 3). Among 4 fractions, 2 fractions showed al good coincidence in their clution patterns in DEAE-cellulose chromatography to those of cyclic AMP binding proteins (Figs. 2, 3). This result indicates that cyclic AMP binding protein may consist of at least 2 different binding sites. One of those for norepinephrine is relatively heat-stable, but another for cyclic AMP is labile to heattreatment. Apparent dissociation constants for cyclic AMP binding to the rat brain macromolecule were shown to be $8.3 \times 10^{-8}$ and $2.2 \times 10^{-6} \mathrm{M}$ (unpublished results). Assuming that cyclic AMP binding protein of rat brain has a binding site to norepinephrine other than cyclic AMP, the binding site with high affinity to catechol structure will be closely located to that of cyclic AMP. A possible conformational perturbation of cyclic AMP binding protein due to cyclic AMP binding would interfere with norepinephrine binding to cyclic AMP binding protein. This is a possible explanation for the inhibitory effect of cyclic AMP on norepinephrine binding to the macromolecule. Another possibility is that cyclic AMP binding protein in rat brain cytosol will have only one binding site containing a hydrophobic area, to which catechol structure of catecholamines will have a high binding affinity. Thu former appears to be possible. Physiological and pharmacological significance of catecholamine binding to the macromolecule in a soluble fraction of rat brain remains the subject of future studies.

Acknowledgement: This work was supported in part by research grant, No. 157065 , from the Ministry of Education, Japan.

\section{REFERENCES}

1) Dunnick, J.K. ANd Makint:Tit, G.V.: Biochim. Biophys, Acta 249, 122 (1971)

2) Lefkowit7., R.J. and Harber, E.: Proc. hath. Acad. Sci. U.S.A. 68, 1773 (1971)

3) Ifel kowitz, R.J., Harber, E. and O'Hara, D.: Proc.nath. Acad. Sci. U.S.A. 69, 2828 (1972)

4) De Plazas, S.F. and DFRobfrtis, F.. Biochim. Biophys. Acta 266, 246 (1972)

5) Schramy, M., Foinstein, M., Nam, E., Long, M. and Lassfr, M.: Proc, nath. Acad. Sci. U.S.A. 69, $423(1972)$

6) Cuatricasas, P., Tell. G.P.L., Sica, V., Palzikh, I. and Chang, K.J.: Nature 247, 92 (1974)

7) Kumon, A., Yamamlda, Y. ANd Nishizuka, Y.: Biochem. biophys. Res. Commm. 41, 1290 (1970)

8) Lowry, O.H., Rosfbrough, N.J., Farr, A.L. And Ranuall, R.J.: J. biol. Chem. 193. 265 (1951)

9) Anton, A.H. and Sayrf, D.F.: J. Pharmacol. exp. Ther. 153, 15 (1966)

10) Bray, G.A.: Analyt. Biochem. 1. 279 (1960)

11) Scatchard, G.: Anr. N.Y. Acad. Sci. 51, 660 (1949)

12) Lefkowitz, R.J., Sharp, G.W.G. and Harber, E.: J. biol. Chem. 248, 342 (1973)

13) Levitzki, A., Allas, D. ANd StF.Fr, M.I.: Proc.nath. Acad. Sci. U.S.A. 71, 2773 (1974)

14) Koretz, S.H. AND MARINETTI, G.V.: Biochem. biophys. Res. Commin. 61, 22 (1974)

15) LET, C.-J.: Brain Re.s. 81, 497 (1974)

16) Lefkowitz, R.J.: Biochem. biophys. Res. Commun. 58, 1110 (1974)

17) LefkOwITZ, R,J.: Phamacol. Rel. 25, 259 (1973)

18) Bilftikian, J.P. And Aurbach, G.D.: J. biol. Chem. 248, 5584 (1973)

19) Clatrecasas. P.: J. biol. Chom, 246, 7265 (197I)

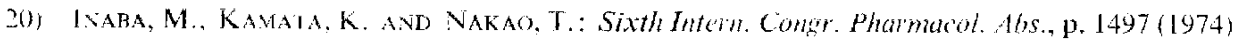

